\title{
A Study of the Employment Situation of English Major Graduates of Application-Oriented Universities in China-A Case Study of Ningbo Dahongying University
}

\begin{abstract}
XIE Chen-ye
Ningbo Dahongying University, Ningbo City, China

The study investigates the present employment situation of the English Major graduates from an Application-oriented University in Zhejiang Province. For those who graduated three years ago, most of them are employed in schools, foreign trade companies, and state-owned enterprise, which are usually well-paid and stable. Twenty percent of them are not satisfied with their jobs. On the other hand, the fresh graduates will firstly focus on high benefits, job stability, and personal interest in job-hunting. However, their high expectation for salary and the enterprise's extremely strict requirement lead to the difficulties of job-hunting. Recently, the university takes some feasible measures, such as Maker Lecture and Teacher Cultivation Workshops, which can effectively promote the practical ability and the core competitiveness of the English major graduates.
\end{abstract}

Keywords: English major, employment situation, Application-oriented Universities

\section{Introduction}

With the change of higher education from "elite education" to "public education", the enrollment scale of universities has been expanding year by year. However, the increasingly enrollment rate has directly resulted in the difficulties of employment of university graduates. From 2003 to 2015, the total number of college graduates has increased from 2.12 million to 7.49 million, 3.53 times than 12 years ago. In 2016, there were 7.56 million college graduates, reaching the top record in history. It was called as "the Toughest Year of Job-hunting". However, the officers in the National Human Resources and Social Security Department estimate that the total number of national college graduates will reach about 7.7 million in 2017. Besides, there are overseas students and the previous graduates who want to switch a job or even do not have a job yet, so finally there will be about 15 million people competing with each other at the same time in the job market. The growth rate of college graduates is much faster than the quantity demanded by the whole society. Meanwhile, the acceleration of economic globalization requires the employers to hire graduates with higher quality and capability. Therefore, English major graduates are confronted with tough challenges now. The purpose of this study is to analyze the present employment situation of the previous English major graduates and graduating students from anapplication-oriented university in terms of many aspects. Besides, based on the problems found in the research process, some effective advice will be put forward to overcome these problems.

XIE Chen-ye, college student, bachelor, Major in English Education, Ningbo Dahongying University, Ningbo City, Zhejiang Province, China. 


\section{Literature Review}

Several scholars and educators in Western countries notice that with the development of capitalist social economy, the employment problems of college students are increasing. John Robst (2007) found that college graduates may take a job which is unrelated to their college major and the mismatch between a worker's education and job is due to over-education and their pursue for higher salaries. Those students who receive the higher education are more likely to refuse the lower income career after graduation and this would lead to the problem of unemployment throughout the whole society. What is more, from the perspective of their income expectation, college students often overestimate their competitive ability and actual ability. Albrecht and Vroman (1992) pointed out that the jobs chosen by college students are affected by the income. If the salary is higher than their expectation, the graduates are willing to take the job rather than sticking to their interest. Income expectations are greatly influenced by family members, friends, colleagues, standards of living, and social status. Excessive income expectation is also a major cause of low employment rates. Albrecht and Axell (1984) indicated that holding a correct attitude is a key step for graduates when finding the job.

Some scholars in China have also researched on the employment situation of English major graduates. FENG Yu and CHEN Ying (2016) pointed out that English major graduates have no distinct advantages in job market, because with the internationalization of China, the number of people who can speak English fluently is on the rise. Besides, the courses offered by colleges and universities fail to meet the needs of the companies and the society, because most of the English major graduates master language knowledge better than the professional knowledge needed for a specific job and they also lack the practical experiences. LAI De-sheng and TIAN Yong-po (2005) found that the university graduates are facing the choice of working in the rural labor market and the urban labor market. Due to the enormous differences of job opportunities, incomes, social welfare, and living environment between the urban and rural jobs, most of the graduates will unhesitatingly choose to work in the urban area. Thus, this will definitely increase the competitiveness pressure of the urban employment. All of these factors lead to the employment dilemma for college graduates.

\section{Research Design}

\section{Research Subjects}

An application-oriented university with great influence and teaching characteristics in higher education is selected. It is a typical application-oriented university in Zhejiang of China and it is located in Ningbo, which is an economy developed city in the Eastern China. In view of economic and regional advantages, the graduates in this application-oriented university seem to have more opportunities to find relatively better jobs than the graduates in colleges and universities in central and Western China. For the study, 50 graduating students in Grade 4 and 50 graduates who graduated in three years are selected as subjects.

\section{Research Method}

Two questionnaires are designed for previous graduates and the fresh graduates. Questionnaire 1 aims to investigate the employment situation of 50 English majors from 2014 to 2016, collecting the information about their profession, job position, payment and so on. Questionnaire 2 aims to investigate the job expectation of the 50 graduating students, including job intention and salary expectations. The two surveys are conducted with the help of Internet and the school teachers. Finally 100 valid copies for two surveys are collected, 50 for each one. 


\section{Data Analysis}

\section{Analysis of the Present Employment Situation of the Previous English Major Graduates}

Speaking of the types of work, $55 \%$ of the 50 previous English major graduates are engaged in education and foreign trade industry in the survey. $35 \%$ of the graduates work in education sector, indicating that working in the schools and the education and training institutions is a favorite choice for English majors. The graduates who enter the well-known and state-owned enterprises account for only $10 \%$ of the total, because the state-owned enterprises rarely provide positions for English majors, resulting in a high competition pressure. In consideration of their major, most of the graduates in the survey are willing to work in education and foreign trade industry. However, in case of the tough employment situation, a considerable part of the graduates are forced to choose jobs which seem to have indirectly or even unrelated relationship with their major.

As for their actual salaries, based on the data from the Questionnaire 1, 46\% of the graduates can receive a monthly salary between 3,500-4,500 Yuan. 30\% of them can get 2,500-3,500 Yuan per month and only 14\% of them can get more than 4,500 Yuan. However, according to the employment data published by the Academy of Sciences recently, the graduates in China receive an average monthly income from 2,815 Yuan to 3,334 Yuan within the years of 2010-2014 nationwide, which has increased by $18 \%$. According to the data from the investigation of Max Institute in 2015, the Chinese graduates' average monthly income is only 3,726 Yuan, consistent with the findings of Questionnaire 1. These statistics show that the salaries of the most university graduates are not high.

In terms of job satisfaction in Questionnaire 1, 8\% of the subjects are very satisfied with their current jobs and $30 \%$ are quite satisfied. $42 \%$ of them are comparatively satisfied whether their majors is related to job or not and they also want to contribute their energies to the work. However, the remaining $20 \%$ are not satisfied with the current jobs, hoping to get other better job opportunities. Meanwhile, $85 \%$ of the subjects change at least one or even more jobs within three years after graduation and $36 \%$ of them choose to work in the present position for a period of time at first and then to change jobs. The phenomenon of frequent job-hopping reflects the current employment problems of the graduates, such as dissatisfaction with salary and benefits and lack of interest in work. The survey also shows that compensation and benefits are very important factors that $90 \%$ of the graduates will surely consider when choosing jobs. At the same time, when the enterprises recruit employees, they always attach great importance to the combination of the professional knowledge and ability and even require the corresponding qualification certificates. However, nearly $80 \%$ of the graduates have passed the National English proficiency tests, but their lack of ability to work in a specific position or to communicate with others effectively, which will definitely lead to the failure of obtaining a satisfactory work.

\section{Analysis of the Job Expectation of the Fresh English Major Graduates}

Firstly, based on the results of Questionnaire 2, the conclusion can be drawn that $80 \%$ of the subjects choose to apply for jobs after graduation directly and immediately. $14 \%$ of them choose to apply for postgraduate study at home or abroad. Only $6 \%$ of them choose to start their own businesses.

Secondly, in terms of the salary expectation, $24 \%$ of the Grade 4 subjects who are about to graduate in the application-oriented university, expecting that they could receive a more than 6,000 Yuan salary per month! Their unrealistically expectations have a large gap with the actual salary, which has greatly hampered their enthusiasm for job-hunting. However, it is widely perceived by many Career guidance specialists that in the 
job-hunting process, the graduates should set themselves at the right position, establish the correct values and views on career, and do not only focus on salary, otherwise it will fall into unemployment and desperation.

Thirdly, as for the job intention, according to a multiple-choice question in the Questionnaire 2, the top five on the "most popular jobs" list are school teachers, training institution teachers, foreign trade salesman, enterprise administrators, and civil servants. Firstly, the education sector is still the most popular job for English major students so that the competitive pressure for job-hunters continues to increase. In such a stressful situation, more students who are about to graduate are expected to seize every opportunity for a further study so as to keep them competitive. However, more fresh graduates obviously tend to hunt jobs blindly, which also leads to the low employment rate. Secondly, the graduating senior students, without knowing the actual situation in the job market, are expecting a decent job with a high salary and welfare. $34 \%$ of them expect a salary range from 4,000 to 5,000 Yuan monthly and $24 \%$ of subjects even expect that their salary can reach more than 6,000 Yuan per month. It is made clear that the students who are about to graduate want to get a relatively high pay and welfare, but without properly positioning their own ability. Finally, joblessness of them will definitely become a natural phenomenon.

Finally, in consideration of starting their own business, by comparing the survey of the previous graduates and the fresh graduates, the conclusion can be drawn that only $6 \%$ of the previous graduates and $6 \%$ of the fresh graduates are willing to start their own business. On the one hand, as for the previous graduates, who have at least one or two years of work experience, the biggest obstacle of starting a business is their lack of sufficient initial capital. On the other hand, $80 \%$ of the fresh graduates prefer to hunt a job after graduation immediately. It indicates that starting their own business is still not the best and first choice for them. After all, starting a business needs to overcome the challenges from many aspects, such as the starting funds, work experience, products, staff, and other related issues. The risk is also unpredictable. As for the senior students who are about to graduate, their lack of social connections and work experience has become the biggest obstacle to starting their own business. This profoundly shows that the graduates and the students who are about to graduate have a great gap in social awareness. The difficulties and obstacles they have come across suggest they should seize the opportunities to take part-time jobs so as to accumulate social work experience and lay a solid foundation for starting their own business.

\section{Influencing Factors of Employment of English Major Graduates in the Application-Oriented University}

\section{Personal Factor}

The personal factor is the crucial reason for the unsatisfactory present employment situation. With the rapid development of social economy, the employers' requirements for English majors are increasingly promoted. First of all, according to the subjects' feedback, nearly $87 \%$ of the employers require them to have a strong ability of work and communication. On the contrary, most graduates only focus on the professional knowledge, but have little practical experience, so that their comprehensive ability fails to meet with the needs of society. Second, when it refers to the important and effective factors of job-hunting, $90 \%$ of the graduates consider that the salary and welfare is the most important factor, followed then by the stability of the work, personal interests, second, third respectively. Therefore, when they start working, the graduates put excessive amount of concentration on the unrealistic expectations of incomes, without thinking of other possible but vital factors. The unrealistic expectation is an important factor leading to the terrible employment situation nationwide. 


\section{School Factor}

First of all, based on the results of the Questionnaire 1, 48\% of the graduates regard that the rapid expansion of higher education leads to the surging pressure of competition in the job market and $44 \%$ of the graduates consider that most of the school courses are concentrated on the theoretical study which is useless for practical work experience. However, the enterprises demand the employees with practical ability. Therefore, the widening of college enrollment and the irrationality of curriculum arrangement are decisive factors leading to the low employment rate.

Secondly, universities fail to provide undergraduates some professional teachers to give them additional career guidance. Without group learning and specific instruction, the graduates often feel lonely, frustrated, and powerless when they prepare themselves for the job-hunting or for the postgraduate entrance examination.

Thirdly, although some colleges and universities offer the career guidance courses, most of them are always given in the form of lectures. This kind of guidance only stays in the theoretical level, so the students still cannot have the chance to put it into practice. When they hunt for jobs, they face tough challenges which due to their lack of practical experience.

Fourthly, although many university offer courses on entrepreneurship and some famous and outstanding entrepreneurs are invited to give speeches or lectures on their achievement and successful experience, students still fail to draw up the business plan by themselves or incapably put the plan into practice. Having participated in a lot of entrepreneurial design competition, they still could not perfectly and effectively carry out their entrepreneurial design, because they will meet some actual difficulties when they get down to start their business. Several universities have set up an entrepreneurial park for students, but the lack of management, financial support, and an overall business environment, all of these make the pioneer park less effective and operated only in a small scale. Therefore, the entrepreneurial park cannot meet the purpose of establishment and the actual needs in the process.

\section{Government and Social Factors}

In recent years, the Chinese government and the whole society encourage university students to start their own businesses. However, contrasting results of the two surveys, it can be found that $6 \%$ of the previous graduates and $6 \%$ of the Grade 4 students are willing to try their own business. As an entrepreneur, except for overcoming the lack of social experience and contacts, they also hope to receive some government subsidies on start-up funds and financial aids in the process. These policy and measures are not performed yet, so entrepreneurship seems to be a Holy Grail. In addition, the whole job market is slashing jobs. Firms are more likely to recruit experienced applicants than the ordinary and fresh graduates, in consideration of their companies' own development.

\section{Effective Advice on Improving the Employment Situation of English Major Graduates}

The graduates in application-oriented universities are perceived as stronger practitioners for they have more practical courses. Under the severe employment situation, how to effectively improve the comprehensive quality and enhance the employment rate of English Majors in application-oriented universities has become the dual task for them. Solving the problem of joblessness of university graduates needs the efforts from all directions of the whole society. 


\section{Advice for the Government and the Society}

First, the government should strengthen macro-control efforts and make full use of the Internet, news media, and other channels to release recruitment information in time. Second, the government should provide preferential policies and facilitation measures for entrepreneurship, such as increasing the subsidies, reducing part of the sales tax, and so on. This can encourage and stimulate their ambition to start their own business. Third, as for the graduates of application-oriented universities, job fairs should be especially held for them, in order to meet the employers' higher requirements for practical ability. Fourth, the allocation of urban resources should be properly resolved. The graduates should be encouraged to seek employment opportunities in small towns. College students working as the village officials is a relatively successful measure, but more measures should be introduced and carried out, such as establishing agricultural pioneer parks and offering rural employment subsidies. In the "Internet+" era, rural economy with the help of Internet and high-tech aids is leading the future direction.

\section{Advice for Enterprise Managers}

First of all, the enterprises need to improve the previous employment mechanism. They should not only pursue highly educated talents but ought to give more opportunities for the ordinary graduates. They can also provide a period of training for employees, in order to strengthen their practical ability and stimulate their potential. Second, it is necessary to establish and improve the school-enterprise cooperation mechanism. The enterprises or other organizations can require colleges to cultivate the students according to the standard they have required. They can also provide the internship opportunities for the university students, so that they can obtain part of the work experience and ability in advance. They will be more capable and flexible after graduation. Third, develop the "Internet + " program. The enterprises should connect to the Internet, cloud computing, large data with modern manufacturing for promoting e-commerce. The rapid development of Internet finance is a good chance for college students to innovate and start their own business, which provides favorable opportunities to open up the market platform.

\section{Advice for School Administrators}

According to the investigation, the surveyed application-oriented university has carried out some effective reforms in order to improve the employment rate, which is perceived as a good example for other colleges and universities to learn from.

Firstly, the teaching mode is reformed. All the curriculum are redesigned to meet the requirement of the employers. For example, according to the survey, $66 \%$ of the subjects think that "the Flipped Class" and "Teacher Training Workshops" greatly enhance the professional ability of English major. Flipped Class is an innovative teaching model. The students study actively and are proficient in displaying study results rather than passively accept the knowledge from the teacher. It is a manifestation of comprehensive quality improvement in all aspects. Besides, the chances of working in business visits, part-time jobs, and other practical activities are also provided. Through these activities students can enhance the practical ability and strengthen the professional knowledge.

Second, the school set up a team for graduating students, which has equipped with professional tutors, so that they cannot only timely get help when get into trouble, but also improve confidence and team-work awareness. 
Third, with the development of entrepreneurship, the university set up an independent entrepreneurship college. For each class there are several professional tutors. Students can learn successful entrepreneurial cases and practical experiences in their lectures. They can even get the opportunities to take a part time job in the companies of these outstanding entrepreneurs. In addition, the school has organized Innovation and Entrepreneurship Exposition. By putting the students' projects into practice, the exposition provides more chances for students to exercise.

Fourth, by participating in the Teacher Training Workshop, the student can take part in some primary school teaching and training institution teaching. At the same time, the director of the Teacher Training Workshop and a series of office staff are all students, so that they can have opportunities to contact with the business elites, can participate in the discussion of the school-enterprise cooperation projects, and can enrich their social experience. In addition, the school has carried out college tour on weekend for parents and young children, so the students can make full use of this opportunity to organize practical teaching, promote their mastery of teaching skills, and accumulate more experience in teaching.

Fifth, the school-enterprise cooperation has played an important role for the international trade English major students, providing a large number of part-time jobs to further improve their operational capacity.

\section{Advice for English Major Graduates}

Students are also the core element of the success of employment. First of all, according to the survey, $75 \%$ of employers of the study subjects attach great importance to the educational background and professional competence of English Majors, so it is essential for a college student to master solid practice experience and language ability. Second, graduates should set up a correct outlook on employment and values, be full of confidence in job hunting, and do not pursue high paying jobs without regarding to the career development in the future. Third, they must actively participate in social practice, consolidate the professional knowledge, and enhance the application capacity in order to lay a solid foundation for the future career development. Fourth, graduates have to bear hardships and undertake hard work. No matter what your job is, a hard-working and conscientious attitude is sure to win the praise of employers. It is also a manifestation of the graduates' ability and accomplishment. All of these are what an excellent and premium graduate should have.

\section{Conclusion}

Based on the research, the ways to solve the employment problem of English majors can be better concluded. Firstly, the government should provide appropriate and feasible measures to improve the labor market and the environment for employment and encourage English majors to start their own business. Second, companies should abandon the bias and establish a reasonable employment mechanism and try to be more patient to cultivate a group of talents especially for their companies. Finally, the students themselves should study harder to master professional knowledge and skills at university. They should also accumulate social experience through activities. Meanwhile, by establishing a correct position sense, they should not overemphasize the current salary but focus on future development. The indispensable point is that they should seize every opportunity to start their own business and have a promoting and bright future. In a word, the study has great enlightening and referential significance for promoting the employment situation of English major graduates. 


\section{Reference}

Albrecht, J. W., \& Axell, B. (1984). An equilibrium model of search employment. Journal of Political Economy, 92(5), 824-840. Albrecht, J. W., \& Vroman, S. B. (1992). Dual labor markets, efficiency wages, and search. Journal of Labor Economics, 10(4), 438-461.

Bérubé, M. (1998). The employment of English: Theory, jobs, and the future of literary studies. New York and London: New York University Press.

FENG, Y., \& CHEN, Y. (2016). Discussion on English major graduates employment situationand its countermeasures in Application-oriented Universities. Heilongjiang Science, 7(7), 152-153.

LAI, D. S., \& TIAN, Y. P. (2005). An explanation for "educated unemployment" in China. Economic Research Journal, 11, 111-119.

LAI, Z. (2009). Ten core competent factors for English majors in Chinese university. Foreign Language and Literature, 25(10), $128-132$.

Robst, J. (2007). Education and job match: The relatedness of college major and work. Economics of Education Review, 26(4), 397-407. 